\title{
Promotion of Trilingual Education \\ in Kazakhstan Schools: \\ Online Monitoring Results
}

\author{
Zhanbol O. Zhilbayev**, Lyailya S. Syrymbetova ${ }^{a}$, \\ Manargul Y. Mukasheva ${ }^{a}$, Bakhytgul A. Zhetpisbayeva ${ }^{b}$ \\ and Gulnara T. Smagulova ${ }^{b}$ \\ ${ }^{a}$ National Academy of Education named after Y. Altynsarin \\ 8 Mangilik Yel, Astana, 010000, Kazakhstan \\ ${ }^{b}$ Karaganda State University \\ named after academician E.A. Buketov \\ 28 University Str., Karaganda, 100028, Kazakhstan
}

Received 09.01.2019, received in revised form 28.01.2019, accepted 11.02.2019

This article presents the results of the study determining the education entities' attitudes toward trilingual teaching in schools of Kazakhstan and the extent of their participation in the transition to teaching NMC subjects in English. The authors of the paper have provided some results of an online monitoring study conducted among teachers, parents and students of 7-11 grades. Online survey, statistical manipulation, systematization and interpreting of obtained data served as the main research methods of the present study. The results of the conducted research reveal that the promotion of the trilingual education ideas in Kazakhstan is no longer a trend, but it is a "way of life" for the majority of students and teachers in the country. The support for teaching NMC subjects taught in English is an obvious phenomenon nowadays in Kazakhstan. The materials of this article may be essential and beneficial for the researchers of multilingual education issues, as well as for comparative studies in the field of teaching English.

Keywords: trilingual education, education in English, natural-mathematical cycle (NMC) subjects, willingness to teach NMC subjects in English.

Research area: pedagogy.

Citation: Zhilbayev, O.Z., Syrymbetova, L.S., Mukasheva, M.Y., Zhetpisbayeva, B.A., Smagulova, G.T. (2019). Promotion of Trilingual Education in Kazakhstan Schools: Online Monitoring Results. J. Sib. Fed. Univ. Humanit. soc. sci., 12(2), 285-301. DOI: 10.17516/19971370-0395.

(c) Siberian Federal University. All rights reserved

* Corresponding author E-mail address: zh.zhilbayev@gmail.com

This work is licensed under a Creative Commons Attribution-NonCommercial 4.0 International License (CC BY-NC 4.0). 


\section{Introduction}

The modern education system of the Republic of Kazakhstan is characterized by the structural reforms at all its levels and links. The greatest burden in this regard is experienced primarily by the system of school education. Thus, occupying one of the central links in the entire system, secondary education has been undergone fundamental changes and the revision of the main aspects in all levels, starting from preschool and finishing with higher and postgraduate education. The pedagogical laws of integrity and continuity explain these changes, since the innovations have been introduced in the secondary school, without securing the "input" from the preschool education level and the "output" at the higher education level, therefore the education system can be greatly weakened by reducing their social and pedagogical value.

One of the significant and essential aspects of innovation in school education is a phased transition to trilingual education, where the goals and objectives of learning English are the most acute and complicated issue.

Thus, N. Nazarbaev, the President of the Republic of Kazakhstan, in his message "The third modernization of Kazakhstan: global competitiveness" (Tret'ia modernizatsiia Kazakhstana..., 2017) addressed to the people of Kazakhstan on January 31, 2017, noting in the context of the phased transition to trilingual education that "since 2019 the teaching of some subjects in 10-11 grades will be in English. Two years earlier, the President in "The Nation Plan: 100 specific steps to implement the five institutional reforms of the Head of State Nursultan Nazarbaev" (Plan natsii - 100 konkretnykh..., 2015) had outlined the purpose of the phased transition to English as the main teaching language in high schools and higher education institutions (step 79) as follows, "The main goal is to increase the competitiveness of the graduates and to increase the potential export of the educational sector".

Starting from 2007, the Head of the State constantly and methodically has focused the attention of state bodies and the pedagogical community on this issue. In the article "Looking into the Future: Modernization of Public Consciousness" (Nazarbaev, 2017) he emphasized the importance and necessity of mass and accelerated teaching of the English language in order to increase the competitiveness of Kazakhstan and the importance of a knowledge of the English language by citizens of the country to work in the global world.

The challenge to learn English in Kazakhstan is also emphasized in the following strategic documents: 
1) The State Program on Language Development and Functioning in the Republic of Kazakhstan for 2011-2019 (Gosudarstvennaia programma razvitiia..., 2018), where it is noted that the proportion of people speaking English in the Republic should increase up to $20 \%$ by 2020 , and the proportion of the people speaking three languages (Kazakh, Russian and English) - up to 15\%.

2) The State Program on Education and Science Development in the Republic of Kazakhstan for 2016-2019 (Gosudarstvennaia programma razvitiia..., 2018) specifying the following:

- “... despite the fact that since 2017-2018 in 15 basic higher education institutions providing teachers' training in 4 pedagogical majors in natural-mathematical direction, the shift to the teaching in English with the development of educational programs, textbooks and teaching materials in English for higher education institutions, the need for subject teachers with a knowledge of English remains high;

- in 2017-2018 school year a phased introduction of trilingual education will be launched starting from the $5^{\text {th }}$ grade;

- from 2018, new classes will be opened with English as a teaching language in a pilot mode based on the capabilities of the local executive authorities;

- starting from 2017, scholarships will be annually allocated to the preparatory department in higher education institutions to improve the level of language training;

- starting from 2017-2018 school year in basic higher education institutions, which train personnel for enterprises of the State Program of Industrial-Innovative Development (SPIID), English-language education for 6 majors will be launched for the first time together with the development of educational programs, textbooks and teaching materials in English for higher education institutions. Bachelors are expected to have obtained English proficiency at the C2 level by 2021. Subsequently, master disciplines will be studied predominantly in English as well" (Gosudarstvennaia programma razvitiia..., 2018).

National Academy of Education named of I. Altynsarin focuses on the study of the implementation degree of the above-mentioned ideas in Kazakhstan, and it has been conducting targeted monitoring in recent years on behalf of the Ministry of Education and Science of the Republic of Kazakhstan.

\section{Theoretical framework}

This article presents the main results of our monitoring studies. We have reviewed the following provisions as theoretical foundations: 
The word "monitoring" comes from the Latin word "monitor" that is reminding, observing. At first, this term was often used in ecology, and it meant control, assessment, and prediction of the environment state taking into account the economic orientation of a man. Over the past period of time, this term has received a wider meaning. Now it means a control of action in order to detect its compliance with the expected result (Farman, 2013).

The definition of monitoring and understanding the results of its use give a reason to judge that this concept is most often used when it comes to conducting of a series of specific actions or some mixed activities conducted on the basis of both theoretical and practical developments united by the definition of "monitoring" and serve to clarify the situation in a particular area of practice. Recently, new research directions that can be defined precisely as monitoring ones have emerged. They are world ecomonitoring, space monitoring, media space monitoring, where monitoring is the main working method. It has entered the social sphere where studies that can be categorized as monitoring ones have been already conducted (Monitoring protsessa i rezul'tatov issledovaniia, 2018).

The monitoring is mainly interpreted as constant, scientifically conditioned diagnostic and prognostic observation of the educational process in the sphere of pedagogy.

Monitoring employs different monitoring tools and explanations. However, the monitoring applies a more specific and focused analysis, when the subject of study is deliberately distinguished.

However, such a study differs from the collection of statistics and opinion polls in the fact that its results are the basis for recommendations (Smolyaninova, 2016). This is the actual result and the ultimate goal of monitoring. In general, monitoring can be interpreted as a method of learning practices and experimental science.

This position refers to our case.

\section{Statement of the problem}

As we have noted above, teaching of natural-mathematical cycle (NMC) subjects in English is the most complex issue in promotion of trilingual education in Kazakhstan. Besides, the employees of the National Academy of Education named after I. Altynsarin have chosen the information that allows us to characterize the country's readiness for this process: it is primarily about teachers, parents and students. 


\section{Methods}

The authors have applied methods of online-survey, data analysis and interpretation preparing the materials of the present paper.

For the online-survey the authors compiled the list of 4,815 Kazakhstan secondary schools excluding elementary and primary schools as well as 637 pilot schools that started teaching of one or several NMC subjects in English. From this given list, representatives from 2,571 schools took part in the monitoring, which amounted to $53.4 \%$. This shows the representativeness of the monitoring sampling. The number of respondents (Table 1-2) is also impressive.

Table 1. Information about the contingent of online survey respondents

\begin{tabular}{|c|c|c|}
\hline Students & $\begin{array}{c}\text { Teachers (physics, chemistry, biology, } \\
\text { computer science teachers) }\end{array}$ & Parents \\
\hline 128,800 & 9,392 & 91,091 \\
\hline
\end{tabular}

Table 2. Information about the teachers of NMC subjects who participated in the onlinesurvey

\begin{tabular}{|c|c|c|c|c|c|c|c|}
\hline \multirow{2}{*}{$\begin{array}{c}\text { Name of the subject being } \\
\text { taught }\end{array}$} & \multirow{2}{*}{ Total } & \multicolumn{3}{|c|}{ Teaching in Kazakh } & \multicolumn{3}{|c|}{ Teaching in Russian } \\
\hline & & Total & Village & Town & Total & Village & Town \\
\hline Physics & 2,375 & 1,683 & 1,207 & 476 & 692 & 467 & 225 \\
\hline Chemistry & 2,001 & 1,409 & 1,035 & 374 & 592 & 385 & 207 \\
\hline Biology & 2,385 & 1,619 & 1,143 & 476 & 766 & 501 & 265 \\
\hline Informatics & 2,631 & 1,802 & 1,249 & 553 & 829 & 499 & 330 \\
\hline Total & 9,392 & 6,513 & 4,634 & 1,879 & 2,879 & 1,852 & 1,027 \\
\hline
\end{tabular}

The teachers were asked to answer 13 questions; the students of 7-11 grades answered 6 questions; their parents answered 7 questions.

\section{Results and Discussion}

The results of the online-survey: teachers

The credibility of the answers of the responded teachers is caused by the fact that they have a considerable work experience (more than 10 years) and high qualification levels, as only the teachers of the $1^{\text {st }}$ category and the highest category participated in the survey (Fig. 1). 

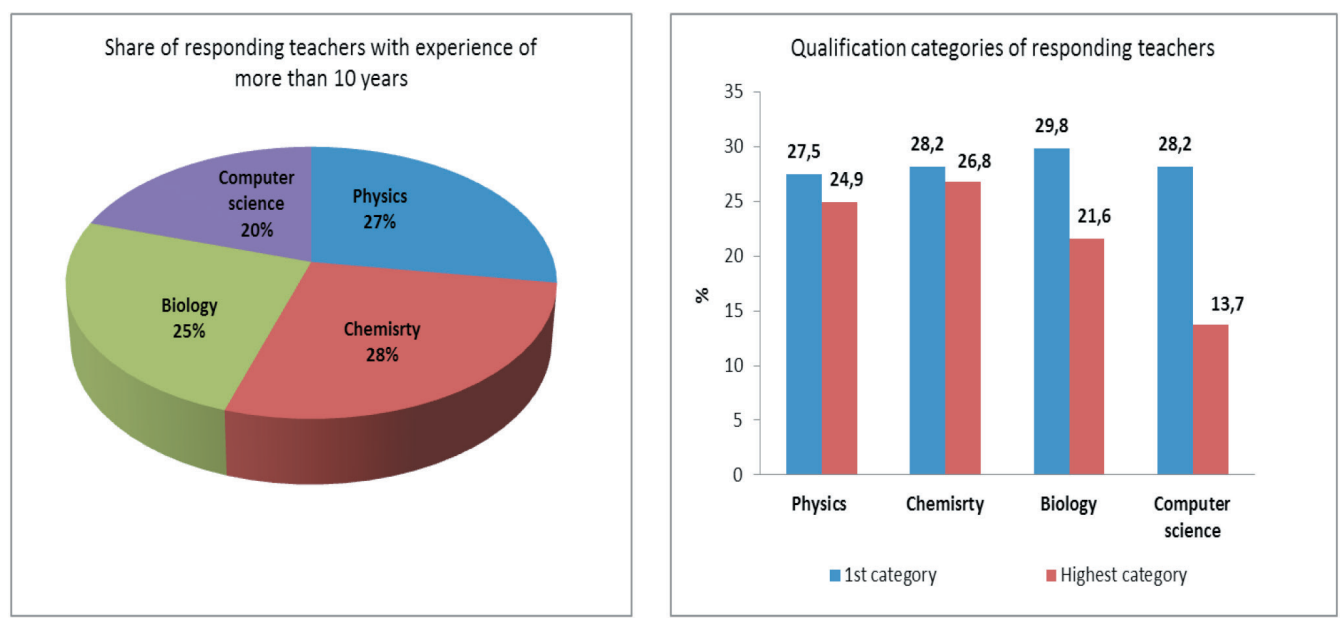

Fig. 1. Stratification of the respondents by subjects and qualification

The answers of the respondents clearly show that the teachers choose mainly the $7^{\text {th }}$ grade to teach NMC subjects in English. At the same time, it should be noted that stable trends for the transition to English when teaching NMC subjects have emerged, i.e. there are teachers who began to teach their subjects in English due to their personal commitment (Fig. 2).

The teachers' intention to study English (Fig. 3) is a particularly important indicator of NMC teachers' willingness to turn to English when teaching their subjects: the number of such teachers accounted for the overwhelming majority, from $65 \%$ and above.

These indicators are justified largely by the results of the teachers' self-assessment of their English proficiency level: the chemistry teachers were the most vulnerable ones (Fig. 4).
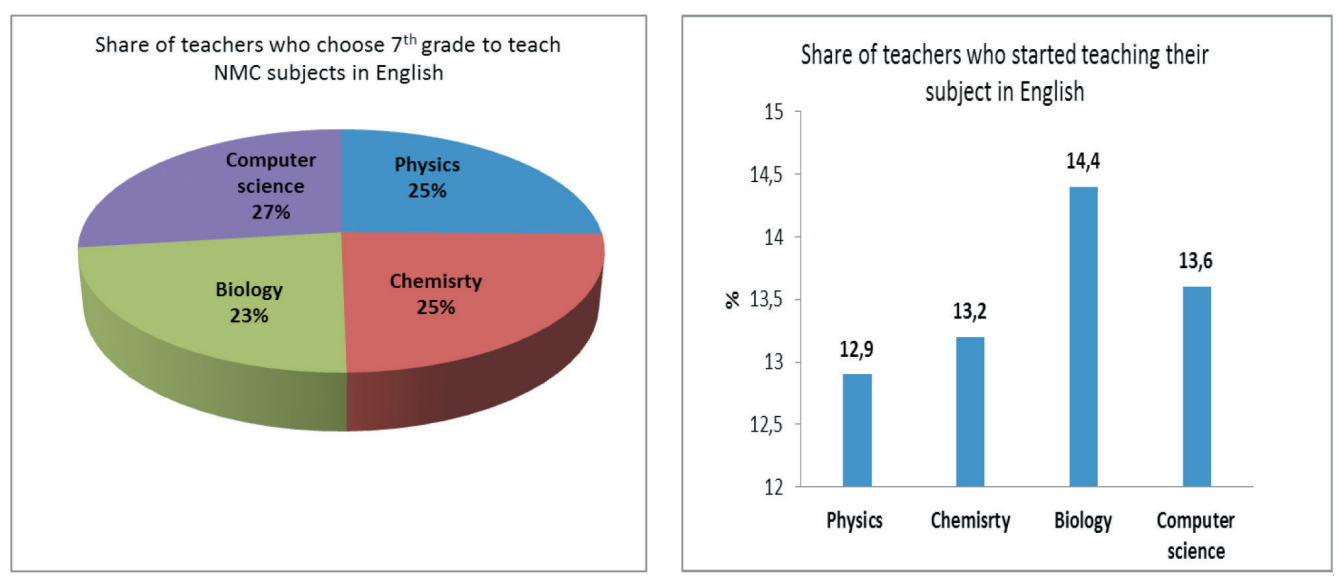

Fig. 2. Proportion of teachers interested in teaching NMC subjects in English who choose the $7^{\text {th }}$ grade 


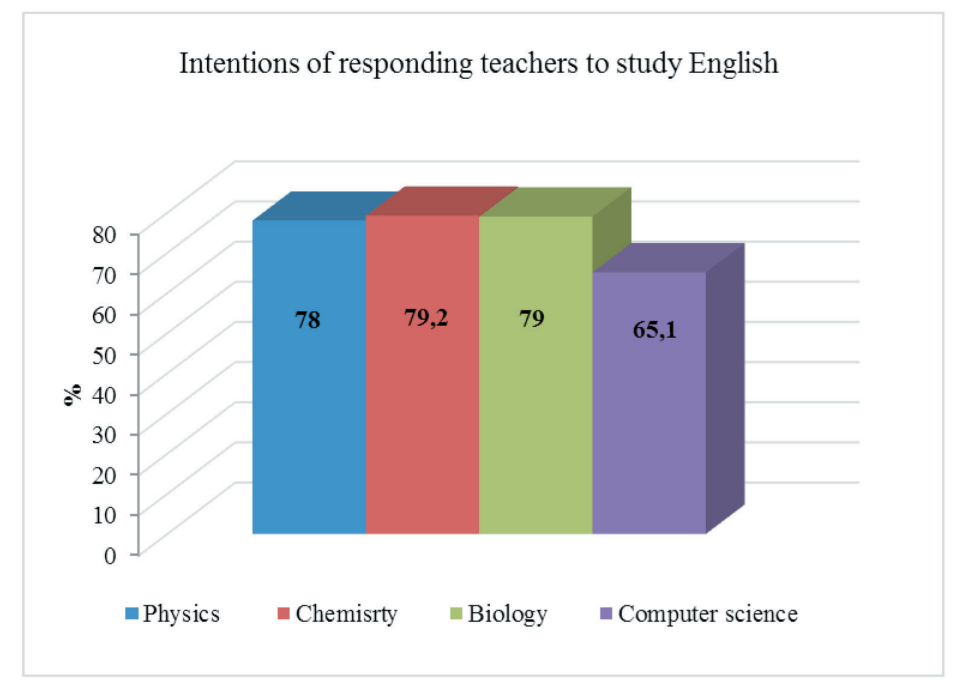

Fig. 3. Intentions of responding teachers to study English

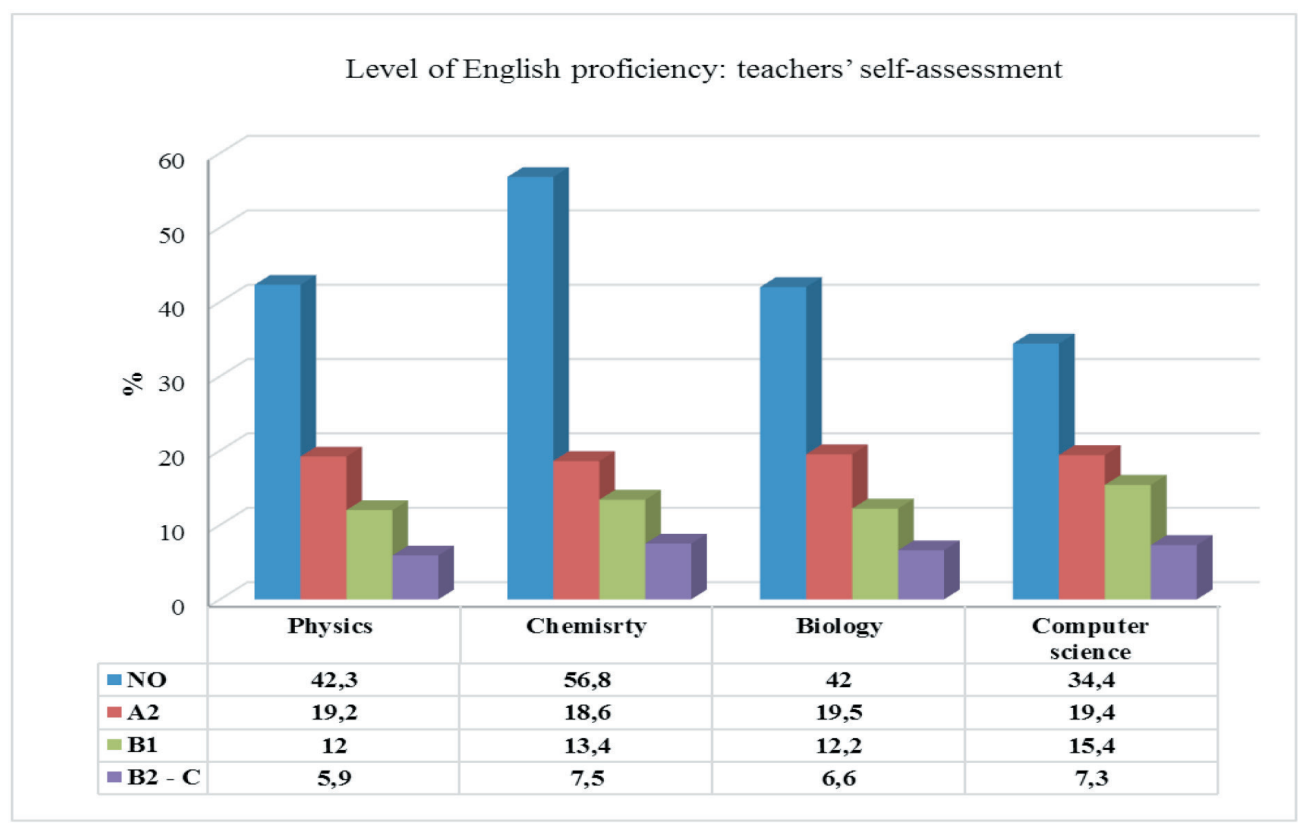

Fig. 4. Teachers' self-assessment of their English proficiency level

Teachers' responses to the question about their English proficiency level correlate in full with the data of the Ministry of Education and Science of the Republic of Kazakhstan about the number of language course trainees arranged for chemistry, physics, biology and computer science teachers (Fig. 5).

Here are some explanations about refresher courses. In the survey, we identified three refresher courses programs relevant to our study. They are: 1) language courses 


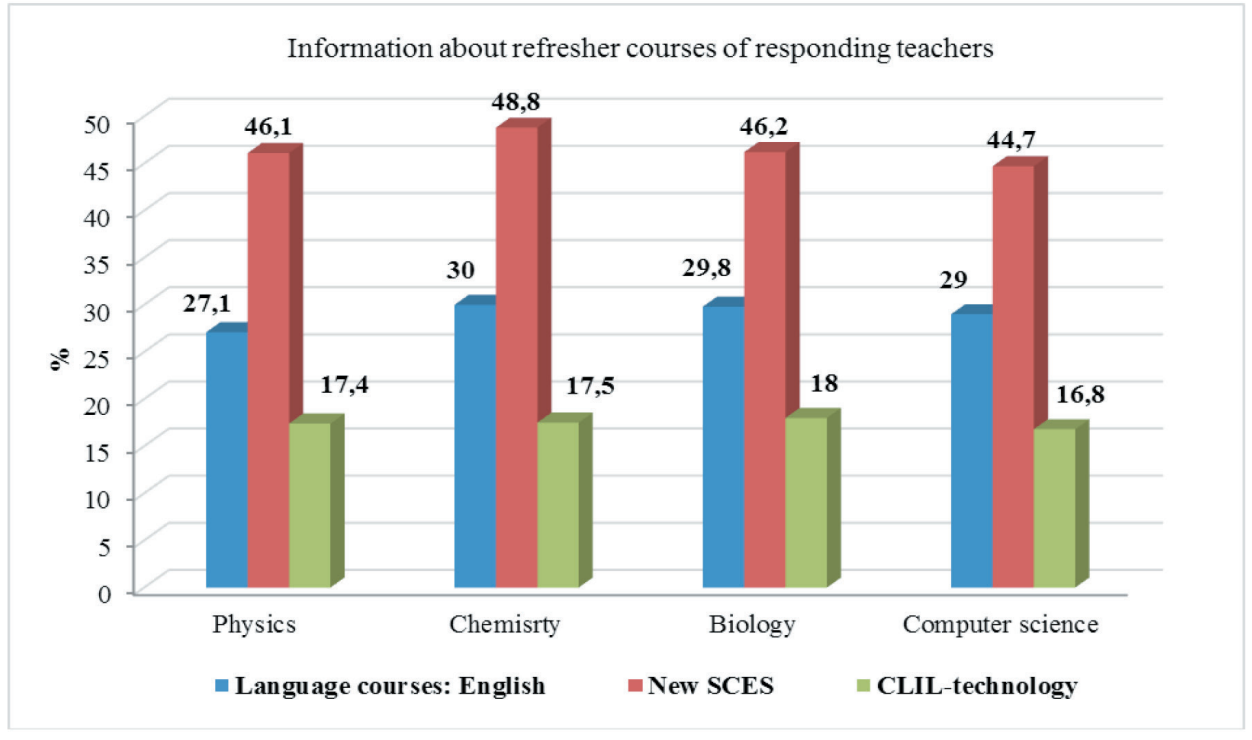

Fig. 5. Information about refresher courses of responding teachers

(hours-long studying English on-the-job and off-the-job), 2) courses under the new State Compulsory Education Standard started to be implemented in Kazakhstan since 2016; completion of the transition to the new standards is planned for 2020, 3) CLIL technology courses, i.e. content and language integrated learning: recently English courses for NMC subject teachers have been expanded and supplemented by the materials according to this technology.

Regarding the ideas of the responding teachers about immersion into English, we note that they have the same opinion: as the NMC teachers believe, the study of their subjects should start from the $7^{\text {th }}$ grade (except for computer science teachers - they consider it is possible to study their subject in English starting from the $5^{\text {th }}$ grade) in the partial immersion mode with a gradual transition to a full immersion by the $10-11^{\text {th }}$ grade.

\section{The results of the online-survey: students}

As we have already noted that 128,806 students took part in the online-survey. The number of the respondents from Kazakh-medium schools exceeded the number of the respondents from Russian-medium schools by 2.5 times, and in the context of a village/town, the students from village schools turned out to be more active (Fig. 6).

As is seen from the materials in Fig. $8,7^{\text {th }}$ graders were among the most active responding students.

The students were asked to answer six questions. The first one was aimed at the self-assessment of their own English level. Judging by the self-assessment results, it 

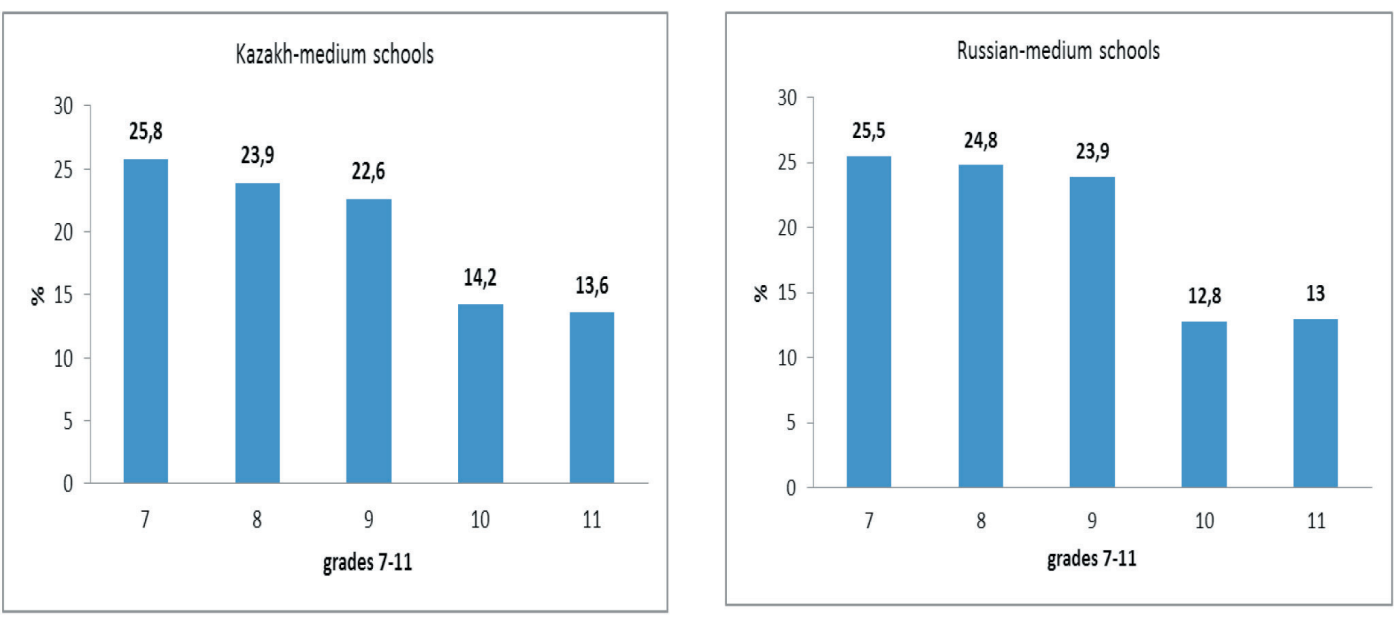

Fig. 6. Contingent of responding students (grades 7-11)
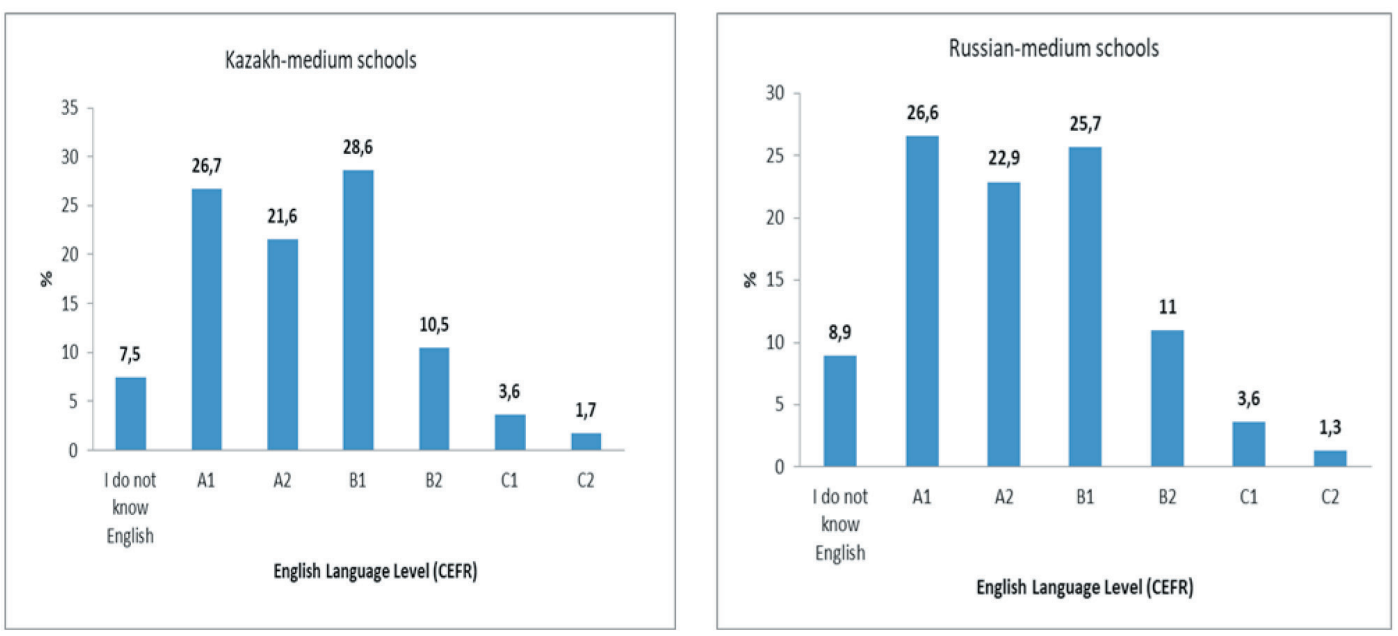

Fig. 7. Self-assessment of proficiency in English by responding students (grades 7-11)

turned out the perceived share of the students speak English at A1, A2 and B1 level (Fig. 7).

The answers to the second question specify the fact that the overwhelming majority of students study English only at school lessons (Fig. 8).

At the same time, the students in Russian-medium schools were more active in learning English outside school (for example, in language centers, at home).

However, the students of Kazakh-medium schools turned out to be more motivated to learn English. 

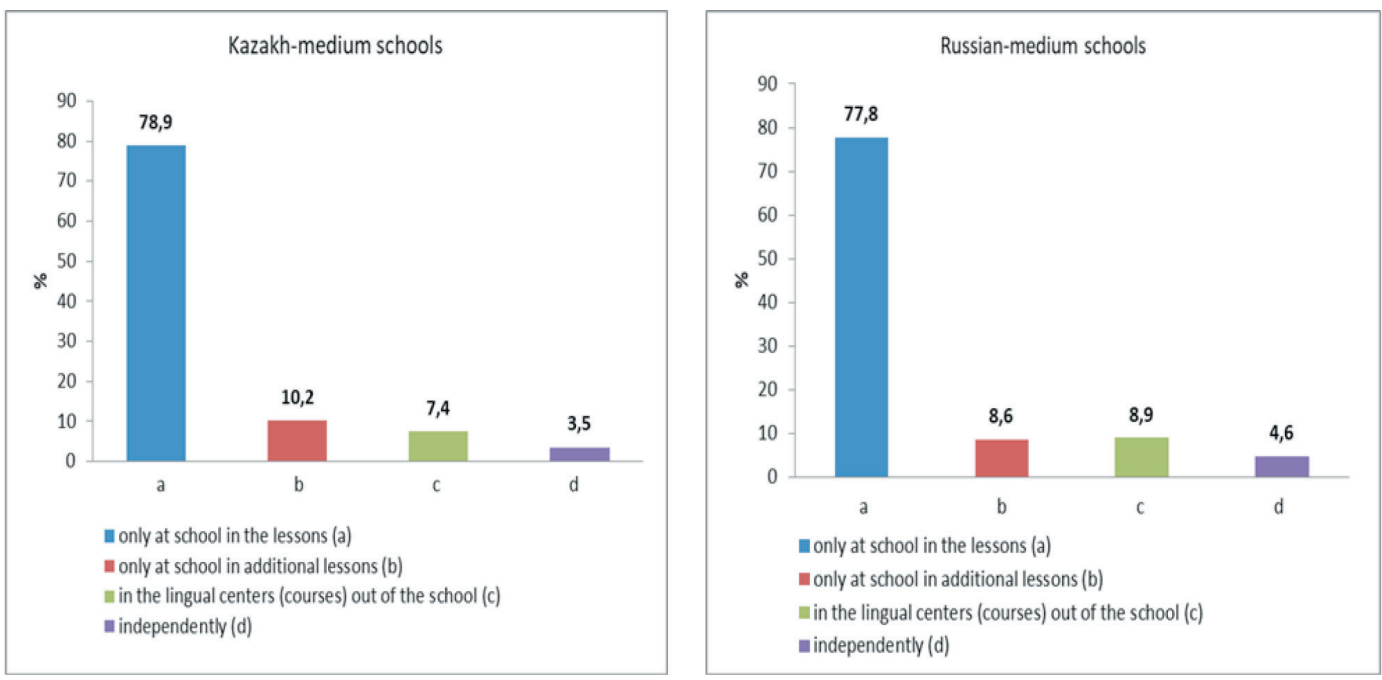

Fig. 8. Information about English learning (grade 7-11)
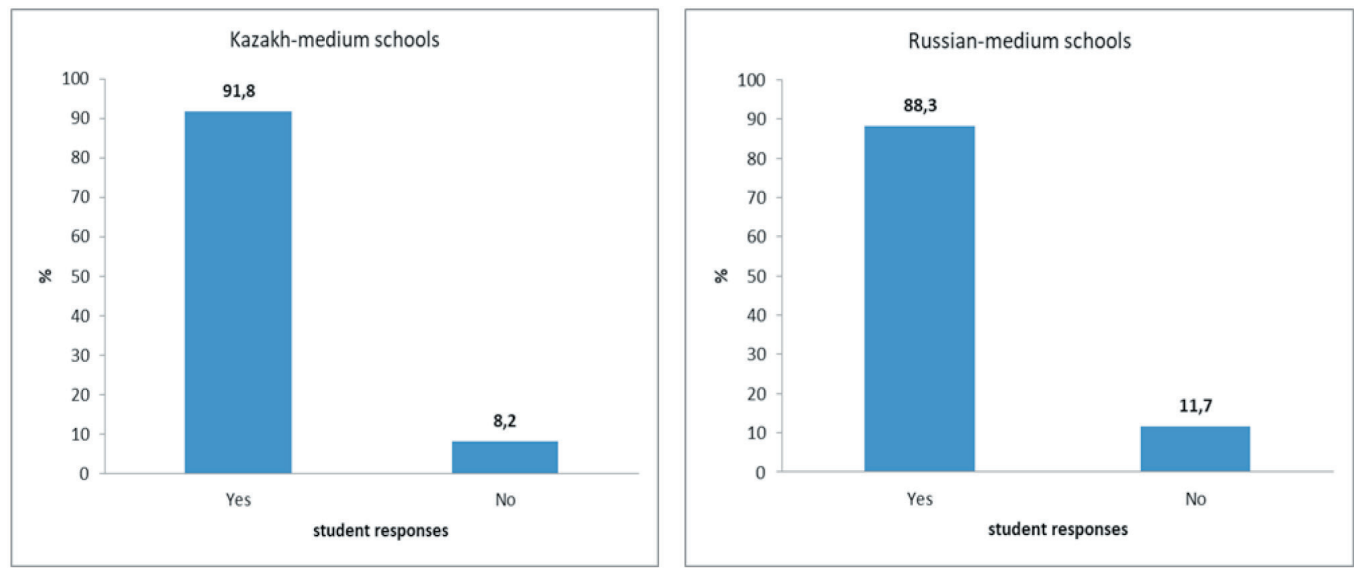

Fig. 9. Information about the students' motivation to improve English proficiency (grades 7-11)

The answers to the question "What subject in your grade is taught in English?" show that computer science is preferred to be taught in English among other NMC subjects with physics mentioned next to it (Fig. 10).

This result seems to be quite correlative within the logic of the teachers' answers to online-survey questions. Indeed, computer science is a subject based on English.

The desire of the majority of the respondents to study one or more subjects in English can be noted as a positive trend. Besides, we should note a substantial difference in motivation: the children from Kazakh-medium schools show a bigger motivation than their peers from Russian-medium schools do (Fig. 11). 

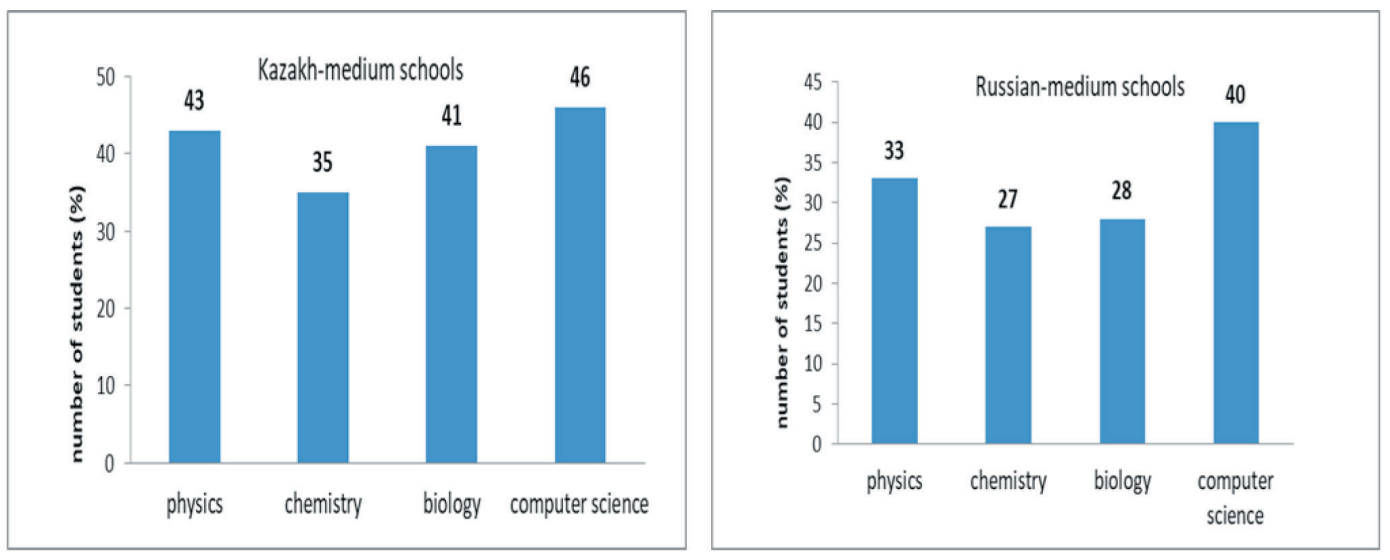

Fig. 10. Information about subjects taught in English
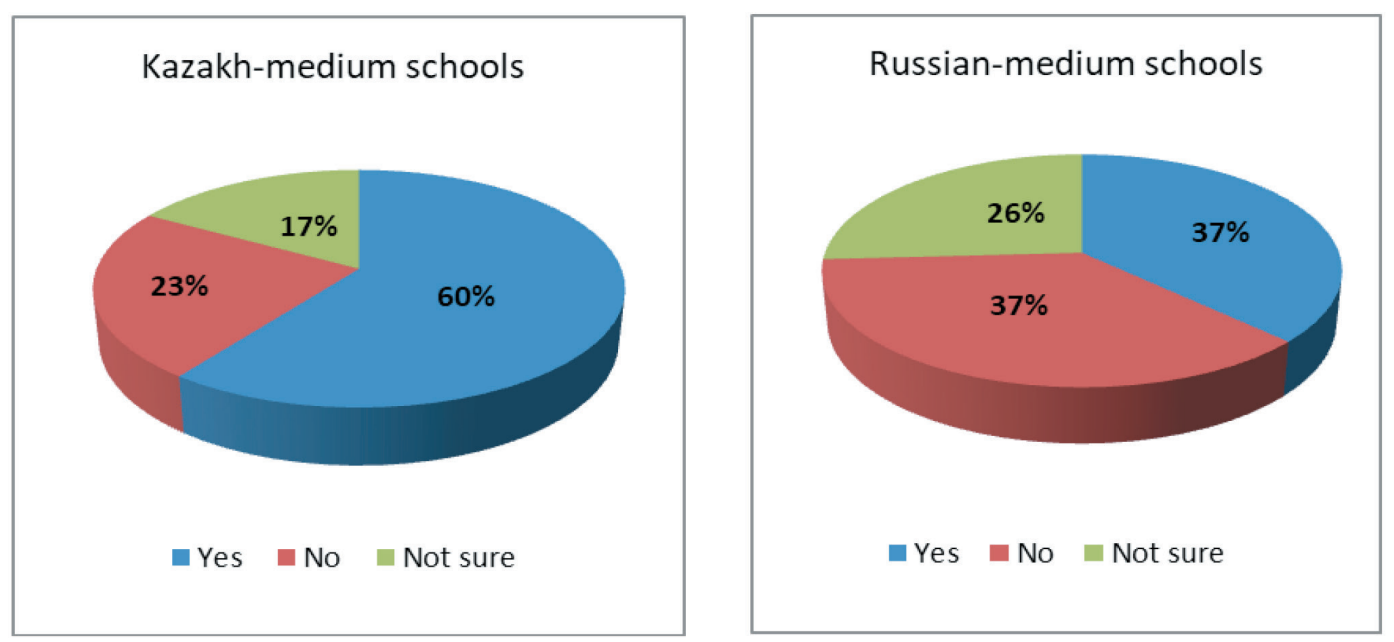

Fig. 11. Information about the students' motivation to study one or more subjects in English

We should also note here that the unacceptable position of the children from Russian-medium schools is categorical: more than a third of the respondents choose the answer "no". Besides, there are more doubters in those schools than in Kazakhmedium schools even among high school students, who, as a rule, intend to continue studying in higher education institutions (Fig. 12 and 13).

In general, the survey among the students enables us to state positive trends in promotion of the goals for teaching NMC subjects in English.

\section{Online-survey results: parents}

Practically the same tendencies can be observed based on the analysis of the parents' answers who were asked seven questions. In particular, the vast majority of 


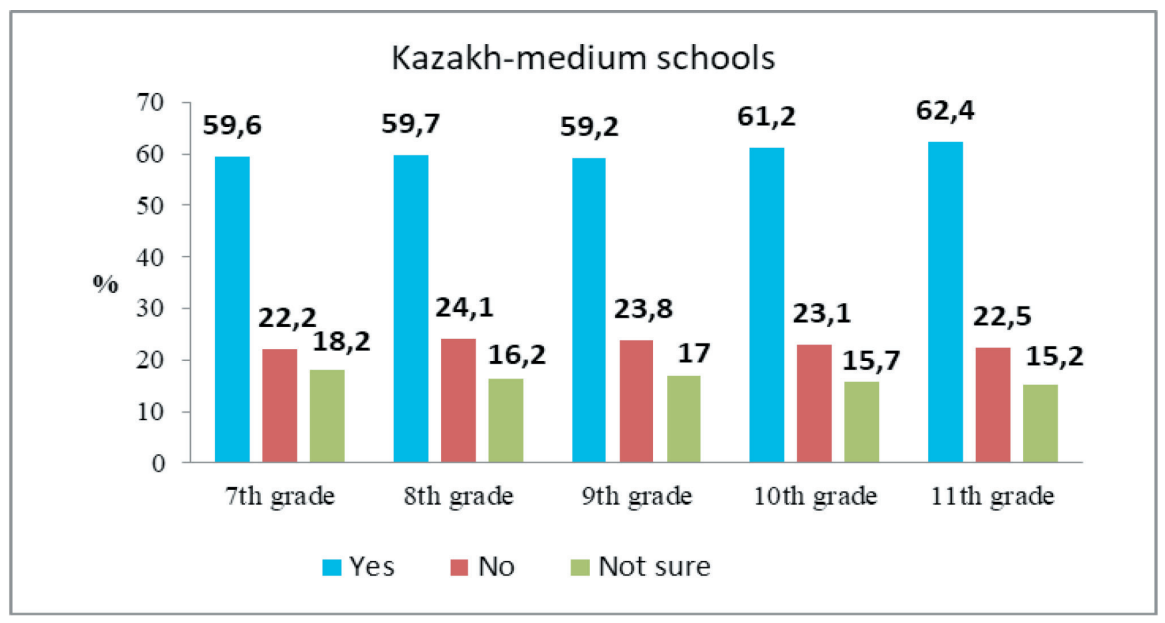

Fig. 12. Information about the intention of students to study one or more subjects in English (by grades)

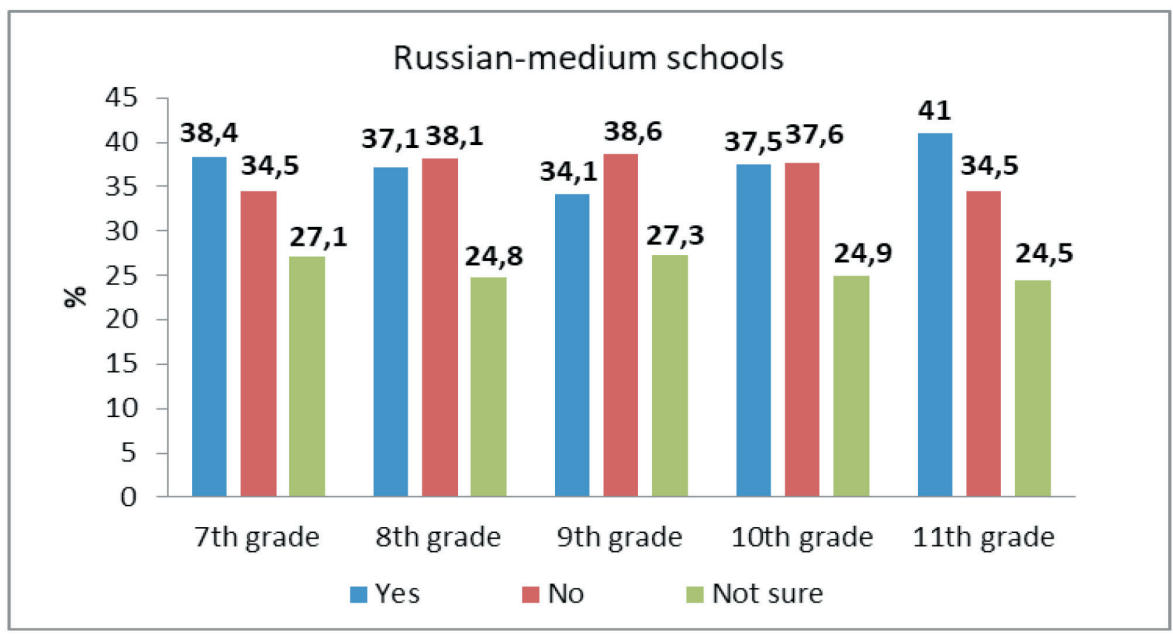

Fig. 13. Information about the intention of students to study one or more subjects in English (by grades)

the parents from Kazakh-medium schools support the idea of teaching one or more subjects in English; however, Russian-medium schools had more doubters (Fig. 14).

At the same time a large proportion of the parents think that in the $10^{\text {th }}$ grade their children will be ready to study one or more subjects in English (Fig. 15).

\section{Conclusion}

Our study has showed that skillful teachers with an experience of over 10 years dominate among the respondents, a little more than half of them have the highest and 

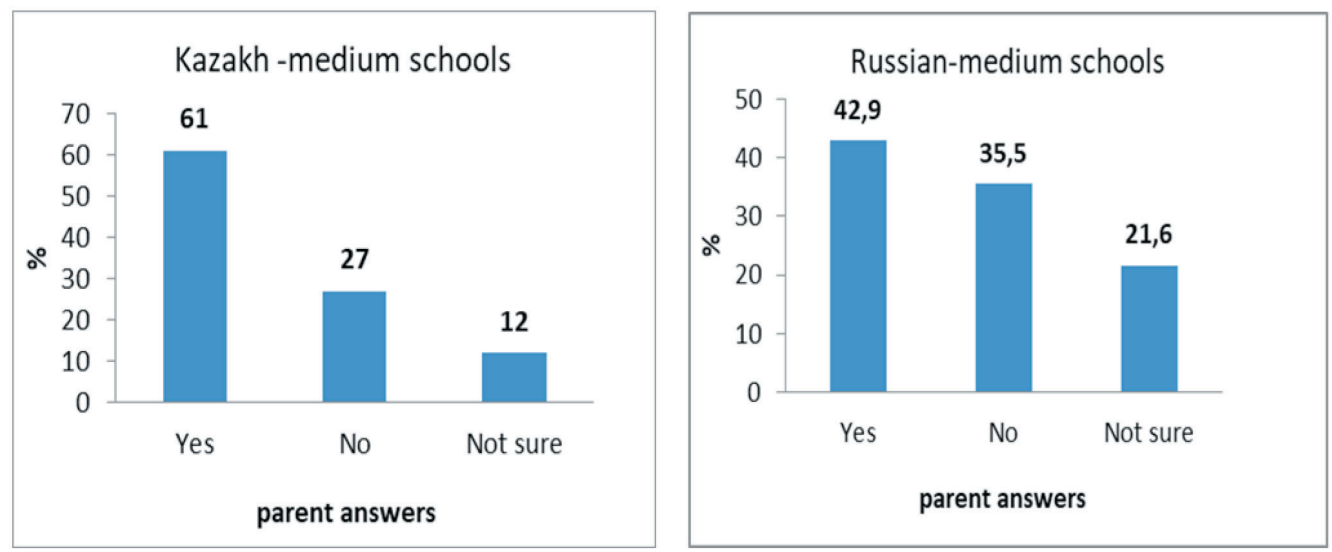

Fig. 14. Answers of the parents to the question

"Do you support the idea to teach one or more subjects in English?"
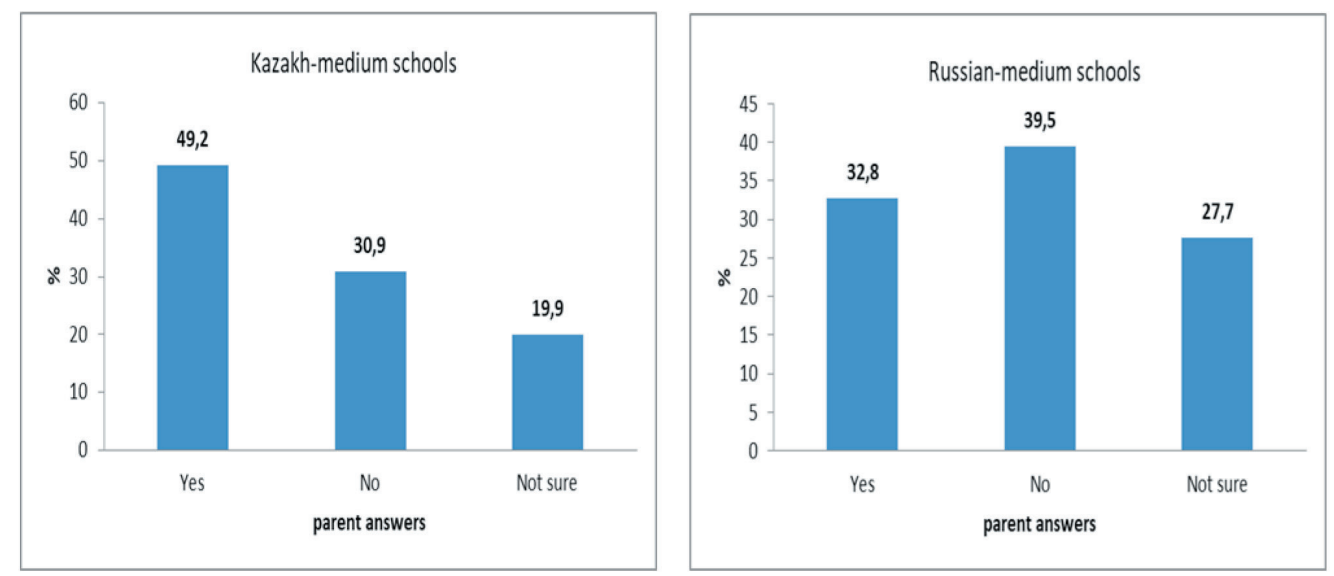

Fig. 15. Answers of the parents to the question

"Is your child ready to study one or more subjects in English in the $10^{\text {th }}$ grade?"

first qualification categories. From this it follows that the answers to the questions are qualified.

The data on the qualitative teaching staff indicate the average qualification level of biology, physics and chemistry. The teachers of computer science showed a lower level: a third part of the respondents do not have the qualification category, despite the indicators of teaching experience, while teachers in village schools make a significant part here. In this regard, participation of NMC subjects' teachers in the certification process under the new system should be stimulated. It is referred not only to computer science teachers. 
The monitoring data shows that approximately 13\% of NMC subjects' teachers have already started teaching their subject in English. If we take into account that the respondents did not include teachers of pilot schools (527), we may state a good start for the performance of Step 79 of the Nation's Plan. It is noteworthy that the teachers' activity in village schools was greater.

In general, all four subjects are taught in English in terms of a variable component (electives, study groups, additional classes, etc.) and in the framework of extracurricular activities in NMC subjects. But in many cases NMC subjects' teachers point out that their subjects are taught within the framework of an invariable component of the curriculum. These teachers have the required English proficiency level (B1-C1) and work in specialized schools for gifted children and Educational and Innovative Lyceums.

The four subjects are taught mostly in English in the $7^{\text {th }}$ grade and in a partial immersion mode, which confirms the conclusion about a successful launch. This is also confirmed by the indicators of the level of English proficiency of NMC subjects' teachers. Here we can observe the following situation: about $19 \%$ of the respondents speak English at A1-A2 levels and 12\% of the respondents speak English at B1 level; at the same time a considerable number (one third of the respondents) of the teachers have relevant certificates, although only $6 \%$ of them have the required level that should start at least from B2.

The intention and motivation of chemistry, biology, physics and computer science teachers to study and improve English can be evaluated as a positive trend. The number of such teachers is overwhelming - about $80 \%$ of the respondents.

As for the refresher courses of NMC subjects' teachers, we should note that language courses and updated education content courses for NMC subjects' teachers (about 30\% and about 50\% respectively) are more systematic and well-planned in comparison with CLIL technology courses (just over 15\%). This implies the need to intensify the process of studying a special technology of Content and Language Integrated Learning (CLIL) by NMC subjects' teachers.

Regarding the opinion of NMC subjects' teachers about this technology application mode, the absolute majority of them (more than 90\%) consider a partial immersion to be the best option that involves studying the subject terminology, conduction of separate stages of a lesson, studying of individual sections of elective courses, conduction of subject studies, classes, and other extracurricular activities in English. In this case, according to chemistry, biology and physics teachers, the 
immersion should start from the $7^{\text {th }}$ grade, while computer science teachers think it should start from the $5^{\text {th }}$ grade.

Concerning the parents' opinion, most of them support the idea of teaching NMC subjects in English. Moreover, the parents of the students studying in Kazakh-medium schools are more positive-minded (61\%), while the parents of the students studying in Russian-medium schools are less positive-minded (42.9\%). The vast majority of the parents claimed that their children wanted to study English. Besides, the majority of the parents pointed out that they liked the way their children were taught English in school. It should be noted that a large share of the parents consider that their children will be ready to study NMC subjects in English in the $10^{\text {th }}$ grade.

The main conclusion of the survey among the students proves the maturity of a high level motivation to learn English and the intention of the majority of the respondents to study one or several subjects in English. This motivation is higher among the children from Kazakh-medium schools (60.1\%) than among their peers from Russian-medium schools (37.3\%).

In general, the online survey among teachers, students and parents allows us to state positive trends in the promotion of the goals of teaching NMC subjects in English: the majority of the parents do not mind, the teachers and the students are strongly motivated.

The data from the monitoring allows us to take a favourable view of the actions taken in this field of education, as well as to make reasoned decisions about the current issues and the development of successful strategies to teach NMC subjects in English.

A further promotion of this idea requires:

- improving the quality of teaching English as a subject;

- ensuring a high quality of teaching resources;

- post-course support for NMC subjects' teachers;

- targeted training of future NMC subjects' teachers with a knowledge of English and CLIL-competences;

- working with mass media using innovative forms of promotion and explanation among a broad public.

\section{References}

Farman, I.P. (2013). Monitoring kak metod issledovaniia i predstavleniia znaniia [Monitoring as the method of research and knowledge representation], In Filosofiia nauki [Philosophy of science], 17, 256-269. 
Gosudarstvennaia programma razvitiia i funktsionirovaniia iazykov na 2011-2019 gody [State Program for the Development and Functioning of Languages for 20112019] (2018). Available at: http://prokuror.gov.kz/rus/dokumenty/gosudarstvennyyyazyk/o-gosudarstvennoy-programme-razvitiya-i-funkcionirovaniya-yazykov-v

Gosudarstvennaia programma razvitiia obrazovaniia $i$ nauki Respubliki Kazakhstan na 2016-2019 gody [State Program for the Development of Education and Science of the Republic of Kazakhstan for 2016-2019] (2018). Available at: http:// www.government.kz/ru/postanovleniya/postanovleniya-pravitelstva-rk-za-iyul-2018goda/1015600-ob-utverzhdenii-gosudarstvennoj-programmy-razvitiya-obrazovaniyai-nauki-respubliki-kazakhstan-na-2016-2019-gody.html

Monitoring protsessa i rezul'tatov issledovaniia [Monitoring of the process and the results of the study] (2018). Available at: https://spravochnick.ru/pedagogika/metody_ issledovaniya_v_pedagogike/monitoring_processa_i_rezultatov_issledovaniya/

Nazarbaev, N.A. (2017). Stat'ia Glavy gosudarstva "Vzgliad v budushchee: modernizatsiia obshchestvennogo soznaniia" [The Article of the Head of State "Looking into the Future: Modernization of Public Conscience”].

Plan natsii - 100 konkretnykh shagov po realizatsii piati institutsional'nykh reform Glavy gosudarstva Nursultana Nazarbaeva [The Nation Plan: 100 specific steps to implement the five institutional reforms of Head of State Nursultan Nazarbaev] (2015).

Smolyaninova, O.G. (2016). Intercultural Educational Platform and PL2S Center for Developing Tolerance of Krasnoyarsk Region Citizens. [Proc. EDULEARN16 Conference]. Barcelona, 1005-1013.

Tret'ia modernizatsiia Kazakhstana: global'naia konkurentosposobnost' [The Third Modernization of Kazakhstan: Global Competitiveness] (2017). In Poslanie Prezidenta Respubliki Kazakhstan N. Nazarbaeva narodu Kazakhstana ot 31 ianvaria 2017 g. [The message of N. Nazarbaev, the President of the Republic of Kazakhstan, to the People of Kazakhstan on January 31, 2017]. 


\title{
Продвижение трехъязычного образования
}

\author{
в школах Казахстана:
}

\section{итоги онлайн-мониторингов}

Ж.О. Жилбаева ${ }^{\text {, Л.С. Сырымбетова }}{ }^{a}$, М.У. Мукашева ${ }^{a}$, Б.А. Жетписбаева ${ }^{\sigma}$, Г.Т. Смагулова ${ }^{\sigma}$

${ }^{a}$ Национальная академия образования им. И. Алтынсарина Казахстан, 010000, Астана, пр. Мангилик Ел, 8 ${ }^{6}$ Карагандинский государственный университет им. Е. Букетова Казахстан, 100028, Караганда, ул. Университетская, 28

В статье представлены результаты исследования по определению отношения субъектов образования к трехъязычному обучению в школах Казахстана и степени их участия в переходе на английский язык при изучении предметов ЕМЦ.

Авторы статьи излагают некоторые результаты онлайн-мониторинга, проведенного среди педагогов, родительской общественности и обучающихся 7-11 классов.

Основныли методами данного исследования стали онлайн-опрос, статистическая обработка, систематизация и интерпретация полученных данных. Результать проведенного исследования свидетельствуют о том, что продвижение идей трехъязычного образования в Казахстане уже не тендениия, а образ жизни для большинства школьников и педагогов страны. Проявляется ясная картина поддержки идеи преподавания одного или нескольких предметов ЕМЦ на английском языке.

Материаль данной статьи могут быть полезны для работы специалистов многоязычного образования, а также для проведения сравнительных исследований в области обучения английскому языку.

Ключевые слова: трехъязычное образование, обучение на английском языке, предметы естественно-математического иикла (ЕМЦ), готовность к обучению предметам ЕМЦ на английском языке.

Научная специиальность: 13.00.00 - педагогические науки. 